\title{
PEMANFAATAN INFRASTRUKTUR DAN RUANG PASCA PEMBANGUNAN INFRASTRUKTUR DI DESA KERTA, PAYANGAN, GIANYAR
}

\author{
Desak Putu Korpiyoni ${ }^{1}$ \\ 1) Magister Arsitektur, Universitas Udayana, Denpasar, Bali \\ desakkorpiyoni@gmail.com
}

\begin{abstract}
Indonesia consists of urban areas and rural areas. The problems also can be find it's not only urban areas have many problems, in rural areas have many problems too. Some problems in rural areas which is not complete is lack of infrastructure, which is to support accessibility and productivity distribution of agriculture product, and it has been hampering economic growth in rural areas. In several things needed for support villagers agriculture activities in rural area is design of infrastructure should be compatible with society and public needs in rural area, other than that, the potential in rural area can be visible. Kerta Village located in Payangan District, Gianyar Regency. The consideration of Kerta Village was chosen as an object of research because infrastructure built with massive and followed with space development during six years clearly visible so that until now village tourism has been built. It need requires an analysis can planning and development according to the needs of Kerta Villagers. The objective of this research is to discover the impact of the planning and development of infrastructure in Kerta Village. This research used qualitative method with case study approach. The result of the research is the analysis of planning and development infrastructure in Kerta Village during six years started 2014 until 2019 and also space utilization since the infrastructure development in Kerta Village.
\end{abstract}

Keywords: rural areas, infrastructure development, spatial utilization 


\begin{abstract}
ABSTRAK
Indonesia terdiri dari kawasan perkotaan dan kawasan perdesaan. Tidak hanya kawasan perkotaan yang ditemukan permasalahan, kawasan perdesaan juga ditemukan permasalahan. Beberapa permasalahan di kawasan perdesaan yang belum bisa di tuntaskan adalah kurangnya infrastruktur yang bisa mendukung aksesibilitas, dan produktifitas distribusi hasil pertanian, hal ini menjadi penghambat pertumbuhan ekonomi kawasan perdesaan. Beberapa hal yang dibutuhkan untuk mendukung aktivitas pertanian masyarakat di kawasan perdesaan adalah perencanaan infrastruktur yang sesuai dengan kebutuhan masyarakat kawasan perdesaan, selain itu potensi dari kawasan perdesaan tersebut mulai terlihat. Desa Kerta terletak di Kecamatan Payangan Kabupaten Gianyar. Dijadikannya Desa Kerta sebagai objek penelitian dikarenakan terbangunnya infrastruktur secara masif dan diikuti perkembangan ruang selama enam tahun terlihat jelas sehingga sampai saat ini terbangun wisata desa. Hal ini membutuhkan analisa di setiap tahap perencanaan pada proses pembangunannya, sehingga Desa Kerta selama kurun waktu enam tahun dapat melakukan perencanaan dan pembangunan sesuai kebutuhan masyarakat Desa Kerta. Tujuan dari penelitian ini adalah untuk mengetahui perkembangan ruang yang terjadi akibat proses perencanaan dan pembangunan infrastruktur di Desa Kerta. Metode yang digunakan dalam penelitian ini adalah metode kualitatif dengan pendekatan beberapa studi kasus. Hasil penelitian ini berupa analisa perencanaan dan pembangunan infrastruktur di Desa Kerta dalam kurun waktu enam tahun pada tahun 2014 hingga tahun 2019 serta kondisi pemanfaatan ruang pasca pembangunan infrastruktur yang terjadi di Desa Kerta.
\end{abstract}

Kata kunci: kawasan perdesaan, pembangunan infrastruktur, pemanfaatan ruang 


\section{PENDAHULUAN}

Kawasan perdesaan di Indonesia memiliki isu banyaknya kemiskinan. Selain kemiskinan, kurangnya infrastruktur dan tidak mendukungnya keberadaan infrastruktur di kawasan perdesaan, dalam mendukung mobilitas dan produktifitas masyarakat desa juga menjadi isu pada kawasan perdesaan. Menurut Ellis \& Freeman (2004) dalam Prastyanti (2015) penyebab dari banyaknya kantong-kantong kemiskinan di pedesaan adalah rendahnya pendapatan keluarga di pedesaan di seluruh negara yang berkaitan dengan sempitnya kepemilikan tanah dan ternak dan ketergantungan yang tinggi masyarakat pedesaan pada pertanian khusunya tanaman pangan.

Indonesia memiliki program pembangunan nasional yang tidak saja menyasar kawasan perkotaan saat ini, tetapi kawasan perdesaan juga menjadi prioritas utama dalam pembangunan nasional. Salah satunya adalah tercermin dari Nawacita pemerintah pusat saat ini, yaitu membangun Indonesia dari pinggiran dengan memperkuat daerah-daerah dan desa dalam kerangka negara kesatuan. Hal ini diperkuat dengan terbitnya Undangundang Nomor 6 Tahun 2014 tentang Desa. Desa mendapatkan perhatian lebih dari pemerintah, dalam hal ini desa memiliki kewenangan secara penuh untuk dapat mengatur dirinya sendiri. Menurut Asnudin (2009) Pembangunan infrastruktur perdesaan tersebut, dengan pelibatan secara penuh masyarakat setempat dalam setiap tahapan (tahap perencanaan s/d tahap operasional dan pemeliharaan). Pelibatan masyarakat perdesaan dalam pembangunan infrastruktur perdesaan akan memberikan beberapa dampak, antara lain: 1) kualitas pekerjaan yang dihasilkan; 2) keberlangsungan operasional dan pemeliharaan infrastruktur tersebut; 3) kemampuan masyarakat dalam membangun suatu kemitraan dengan berbagai pihak, serta 4) penguatan kapasitas masyarakat untuk mampu mandiri memfasilitasi kegiatan masyarakat dalam wilayahnya. Hal ini berdampak pada perencanaan desa yang akan cenderung tepat sasaran dan sesuai dengan kebutuhan masyarakat desa. Salah satunya adalah kebutuhan terhadap infrastruktur. Infrastruktur pada kawasan perdesaan menjadi kebutuhan dasar bagi masyarakat, untuk dapat memperlancar aksesibilitas dan produktifitas dalam mendistribusikan hasil pertanian.

Kawasan perdesaan dengan kondisi infrastruktur yang tidak dalam kondisi baik, membuat distribusi hasil pertanian 
menjadi kurang maksimal. Jalur dengan kondisi masih berupa tanah tanpa perkerasan membuat mobilitas kendaraan menjadi sangat sulit. Namun saat infrastruktur telah terbangun dan sesuai dengan kebutuhan masyarakat, dampak positif terlihat di kawasan perdesaan tersebut dan masyarakat desa, tidak saja dari kemudahan dari aksesibilitas masyarakat dalam menjangkau suatu tempat dan produktifitas dalam kegiatan pertanian hingga distribusi hasil pertanian, selain itu juga akan berkembangnya potensi yang ada di kawasan perdesaan tersebut.

Keberadaan dan kebutuhan infrastruktur pada kawasan perdesaan memang menjadi topik yang paling sering dalam penelitian kawasan perdesaan. Sebelumnya telah terdapat penelitian sejenis mengenai kawasan perdesaan. Penelitian Suroyo (2014) menyusun penelitian mengenai Pengembangan Kawasan Agropolitan di Kabupaten Kulonprogo, Daerah Istimewa Yogyakarta. Penelitian tersebut membahas mengenai ditetapkannya Kabupaten Kulonprogo menjadi kawasan agropolitan pada tahun 2010. Pemerintah daerah belum dapat secara signifikan memberikan dorongan terhadap ketersediaan berupa sarana dan prasarana agribisnis. Minimnya daya dukung tersebut menyebabkan lemahnya peran kawasan agropolitan terhadap pengembangan wilayah di Kabupaten Kulonprogo, serta lemahnya peran sektorsektor industri pertanian yang ada pada kawasan agropolitan yang belum memberikan trickle down effect terhadap sektor-sektor yang ada disekitarnya. Sehingga penelitian tersebut dilakukan untuk dapat mengkaji dari keberhasilan pengembangan kawasan agropolitan di Kabupaten Kulonprogo. Adapun hasil dari penelitian tersebut berupa, pembangunan kawasan agropolitan tersebut belum memberikan dampak yang signifikan terhadap pembangunan perdesaan di Kabupaten Kulonprogo. Faktor yang mempengaruhi adalah kurangnya ketersediaan sarana dan prasarana agribisnis hulu-hilir, tidak didukung oleh SDM yang handal maka perlu peningkatan kapasitas dalam pengelolaan sarana dan prasarana sub sistem agribisnis, serta inovasi teknologi pertanian untuk mewujudkan penerapan kawasan agropolitan.

Penelitian lain yang sejenis adalah jurnal Pranoto et al. (2006) mengenai Pembangunan Perdesaan Berkelanjutan Melalui Model Pengembangan Agropolitan Penelitian tersebut menguraikan mengenai mengembangkan 
konsep pembangunan perdesaan berkelanjutan, melalui model pengembangan agropolitan pada beberapa tipologi dan tingkat perkembangan kawasan agropolitan. Hasil dari penelitian tersebut yang dapat dijadikan sebagai referensi dengan penelitian saat ini adalah pengembangan agropolitan sebagai pendekatan pembangunan perdesaan yang berkelanjutan, dapat tercapai ketika peningkatan produksi pertanian dan peningkatan saran dan prasarana permukiman, transportasi dan pemasaran disertai dengan peningakatan konservasi sumber daya alam, pengembangan agrobisnis dan pembangunan agroindustry, dibarengi dengan perbaikan pemasaran secara berkesinambungan, perencanaan dan pelaksanaan program dibarengi dengan peningkatan peran dan kinerja kelembagaan yang ada. Selain itu penelitian Saraswaty (2013) mengenai strategi pengembangan infrastruktur kawasan agropolitan, menganalisis strategi prioritas dengan penyediaan infrastruktur, dan diharapkan dapat berfungsi sebagai penggerak utama dalam pengembangan kawasan agaropolitan. Dikaitkan dengan penelitian saat ini, strategi dalam penataan ruang kawasan perdesaan dengan infrastruktur yang telah dibangun dan dianalisis mengenai strategi keberlanjutannya. Mengenai obyek penelitian yang serupa, menggunakan penelitian Rudita (2012) mengenai potensi obyek wisata dan keterpaduan dalam pengembangan kawasan agropolitan. Penelitian tersebut mengindikasi bahwa, sektor pertanian dan sektor pariwisata berjalan sendiri-sendiri dan keterlibatan masyarakat masih sangat kurang. Dalam penelitian yang dilakukaan saat ini, akan melihat bagaimana potensi alam dan potensi buatan akan dapat dikembangkan di kawasan perdesaan Kerta dan menganalisis strategi keberlanjutan sektor pertanian dan sektor pariwisata dapat seimbang.

Objek penelitian saat ini terdapat di Desa Kerta. Desa Kerta terletak di Kecamatan Payangan, Kabupaten Gianyar. Desa Kerta merupakan kawasan perdesaan yang pada Rencana Tata Ruang Wilayah (RTRW) Tahun 2012-2032 Kabupaten Gianyar merupakan kawasan perdesaan dan kawasan agrowisata. Dijadikan Desa Kerta menjadi objek penelitian ini adalah terbangunnya infrastruktur secara masif dalam kurun waktu enam tahun, dengan diiringi berkembangnya ruang dengan potensi yang ada menjadi wisata desa, sehingga perlu dianalisa yang mengawali hal tersebut mulai dari perencanaan dan pembangunan infrastruktur. Tujuan 
penelitian ini adalah untuk mengetahui perkembangan ruang yang terjadi, akibat pembangunan infrastruktur kawasan perdesaan Kerta dalam kurun waktu enam tahun, mulai dari perencanaan hingga pembangunan. Sehingga hal yang diperlukan adalah mengenai proses perencanaan dan identifikasi pembangunan infrastruktur yang terjadi selama kurun waktu enam tahun, yaitu tahun 2014 hingga tahun 2019 di Desa Kerta dan menganalisa ruang yang berkembang disekitar infrastruktur yang terbangun pada rentan waktu tersebut, dengan didukung potensi yang ada disekitarnya dan wisata desa terbangun.

Perbedaan penelitian yang dilakukan saat ini dengan penelitian yang telah dilakukan sebelumnya oleh Suroyo (2014) dan Pranoto et al. (2006) adalah Desa Kerta merupakan kawasan perdesaan agrowisata, sehingga pertanian dan pariwisata tergabung dalam satu kawasan perdesaan. Perencanaan infrastruktur dan ruang selain untuk dapat mendukung kegiatan pertanian yang ada di Desa Kerta juga dapat mengembangkan potensi berupa wisata desa yang dapat dikembangkan di Desa Kerta. Penelitian ini juga menunjukkan mengenai tahapan perencanaan infrastruktur dan dampak dari infrastruktur yang telah terbangun terhadap kawasan perdesaan Kerta dan masyarakat Desa Kerta.

\section{KAJIAN PUSTAKA}

Kajian pustaka yang digunakan dalam penelitian ini berupa penataan ruang, pembangunan desa, kawasan perdesaan, infrastruktur, pembangunan kawasan perdesaan.

\subsection{Penataan Ruang}

Menurut Wahid (2014) perencanaan dalam arti yang luas merupakan suatu proses yang berkelanjutan dalam merumuskan dan melaksanakan satu matriks multidimensi dan keputusan yang saing berhubungan yang diarahkan untuk mencapai tujuan-tujuan pembangunan dalam satu jangka dan urutan waktu yang ditentukan dengan cara-cara yang optimal. Tata ruang sebagai wujud penataan ruang pada intinya merupakan sarana untuk mewujudkan pembangunan berkelanjutan. Adapun pembangunan yang berkelanjutan adalah pembangunan yang memasukkan perlimbangan lingkungan hidap dalam kebijaksanaan pembangunan sehingga pembangunan itu tidak saja untuk memecahkan masalah peningkatan kesejahteraan masa sekarang tetapi juga peningkatan kesejahteraan jangka panjang. Konsep pembangunan berkelanjutan mengakomodasikan tujuan pertumbuhan 
ekonomi, tujuan pengentasan kemiskinan dan pengelolaan sumber alam dan lingkungan dalam rangka pemenuhan kebutuhan jangka panjang dan tujuan tersebut konsisten satu sama lainnya. Dalam hubungan tersebut dapat dipahami pentingnya peranan perencanaan tata ruang wilayah dalam konsep pembangunan keberlanjutan sebagai kebijaksanaan pembangunan dalam alokasi sumber alam dan pengelolaan lingkungan hidup untuk menopang pertumbuhan dan pengentasan kemiskinan yang bersifat jangka panjang.

Menurut Gai et al. (2020) pedesaan memiliki sumberdaya sebagai penyangga kehidupan perekonomian masyarakat yaitu pertanian dan lingkungan hidup. Desa juga berfungsi sebagai penyangga interaksi sosial, meningkatkan kesejahteraan masyarakat dan sebagai penyeimbang ekosistem lingkungan. Sumber daya alam dan lingkungan hidup seringkali dianggap sebagai halangan dalam pengembangan pertanian, namun dapat pula dikondisikan dengan memanfaatkan kearifan lokal dan pendekatan lingkungan yang berkelanjutan demi kelestarian alam. Pada tujuan pengembangan pedesaan, pola penggunaan lahan ruang pada desa diutamakan untuk zona konservasi dan fungsi lindung. Hal ini dapat dilihat pada peruntukan ruang kawasan pedesaan, dimana kecenderungan penggunaan lahan adalah zona konservasi dan fungsi lindung. Beberapa tujuan pemanfaatan ruang kawasan pedesaan adalah:

1. Pemanfaatan ruang di kawasan pedesaan diatur untuk membantu meningkatkan kesejahteraan rakyat dan sebagai bentuk penanggulangan dampak negatif pada lingkungan buatan dan sosial.

2. Fungsi kawasan pedesaan ditingkatkan agar menciptakan keseimbangan dalam perkembangan lingkungan dan cara hidup masyarakat.

3. Tata ruang pedesaaan perlu dicapai untuk menciptakan pengembangan kehidupan manusia yang optimal, serasi, selaras dan seimbang.

4. Dinamika pembangunan dan kawasan pedesaan perlu didorong agar mencapai kehidupan pedesaan yang berkeadilan dan tetap melestarikan budaya.

5. Membentuk hubungan fungsional antar kawasan pedesaan. 
6. Mengendalikan peralihan penggunaan lahan secara besarbesaran.

7. Mencegah terjadinya kerusakan lingkungan.

8. Peningkatan manfaat pada sumber daya alam dan sumber daya lainnya.

9. Menciptakan lingkungan perumahan dan permukiman yang layak huni.

10. Menciptakan peningkatan dalam kondisi ekonomi masyarakat pedesaan

Menurut Aldillah (2020) teori pembangunan desa ditujukan guna meningkatkan produktifitas dan potensi wilayah desa dengan teori pembangunan desa. Menurut Rondinelli (1985) dalam Aldillah (2020) yang memprioritaskan integrasi desa kota, sangat terkait dengan pelaksanaan program pembangunan perdesaan, selain itu pemanfaatan hasil pembangunan fisik desa yaitu dengan membangun atau memperbaiki prasarana jalan desa akan menciptakan atau memperbaiki kehidupan masyarakat desa. Dengan adanya pembangunan prasarana jalam, masyarakat dapat menggunakan jalan tersebut dengan berbagai kebutuhan yang mereka perlukan, seperti malaku-kan mobilitas, pemasaran hasil pertaniannya, mangangkut hasil pertanian agar lebih mudah dan lain-lain. Selain itu menurut Rondinelli (1985) dalam Kasikoen (2011) dalam pembangunan spasial jenis-jenis keterkaitan yang utama dapat dikelompokkan dalam 7 (tujuh) tipe, antara lain keterkaitan fisik, keterkaitan ekonomi, keterkaitan pergerakan penduduk, keterkaitan teknologi, keterkaitan interaksi sosial, keterkaitan pelayanan, keterkaitan politik administrasi dan organisasi

\subsection{Perencanaan Pembangunan Desa}

Conyers \& Hills (1990) dalam Solekhan (2014) berpendapat bahwa “Define planning as acontinuous process which involves decisiona, or choices, about alternative ways of using available resources, with the aim of achieving particular goals at some time in the future". (Perencanaan didefinisikan sebagai suatu proses yang berkesinambungan yang mencakup keputusan-keputusan atau pilihan-pilihan berbagai alternative penggunaan sumberdaya untuk mencapai tujuan-tujuan pada masa yang akan datang).

Menurut Salam (2002) dalam Solekhan (2014) berpendapat bahwa "perencanaan adalah usaha membuat suatu pilihan tindakan dari berbagai alternatif yang mungkin dapat tersedia yang meliputi strategi, kebijakan, program, proyek, dan prosedur dalam rangka mencapai tujuan 
organisasi”. Menurut Siagian (2000) mendefinisikan planning sebagai keseluruhan proses pemikiran dan penentuan secara matang daripada hal-hal yang akan dikerjakan dimasa yang akan datang dalam rangka mencapai tujuan yang ditentukan (Solekhan 2014).

Pembangunan desa agropolitan menjadi konsep dalam pembangunan desa. Menurut Rondinelli (1983) dalam Holis (2017) konsep desentralisasi pengembangan wilayah perdesaan atau Development from below (DFB), yaitu dalam hal ini agropolitan atau minapolitan untuk menghadirkan keseimbangan dalam sebuah pembangunan desa, alasan munculnya strategi agropolitan atau tipetipe pembangunan dari bawah.

\subsection{Infrastruktur}

Menurut Grigg dalam Kodoatie (2005) dalam Aldillah (2020), infrastruktur merujuk pada sistem fisik yang menyediakan transportasi, pengairan, drainase, bangunan-bangunan gedung, dan fasilitas publik yang lain yang dibutuhkan untuk memenuhi kebutuhan dasar manusia dalam lingkup sosial dan ekonomi. Pengertian ini merujuk pada infrastruktur sebagai suatu sistem. Dimana infrastruktur dalam sebuah sistem adalah bagian-bagian berupa sarana dan prasarana (jaringan) yang tidak terpisahkan satu sama lain.
Yang artinya bahwa sistem infrastruktur merupakan hal yang selalu berkaitan dengan kehidupan masyarakat baik di dalam sistem sosial maupun sistem ekonomi guna untuk memenuhi kebutuhan dasar manusia secara fisik dengan menyediakan transportasi, pengairan, drainase, bangunan-bangunan dan fasilitas publik lainnya yang digunakan untuk kepentingan masyarakat. Selain itu menurut Kodoatie (2003) dalam Aldillah (2020) infrastruktur dapat juga didefinisikan sebagai fasilitas-fasilitas fisik yang dikembangkan atau dibutuhkan oleh agen-agen publik untuk fungsi-fungsi pemerintahan dalam penyediaan air, tenaga listrik, pembuangan limbah, transportasi dan pelayanan-pelayanan similar untuk memfasilitasi tujuan-tujuan ekonomi dan sosial.

Menurut Grigg (1988) dalam Mustar (2019) infrastruktur dibagi kedalam enam kategori dasar bersar infrastruktur yaitu kelompok jalan (jalan, jalan raya, jembatan), kelompok pelayanan transportasi (transit, jalan rel, pelabuhan, Bandar udara), kelompok air (air bersih, air kotor, semua sistem air, termasuk jalan air), kelompok manajemen limbah (sistem manajemen limbah padat), kelompok bangunan dan fasilitas olahraga luar, Kelompok produksi dan distribusi energy 
(listrik dan gas). Menurut Mustar (2019) untuk menunjang pembangunan desa secara maksimal diperlukan dukungan infrastruktur perdesaan untuk memberikan kemudahan bagi pelaku usaha dalam menjalankan kegiatan ekonominya dan memudahkan masyarakat dalam mengakses fasilitas kebutuhan dasar lainnya. Isu dan permasalahan yang dihadapi pemerintah terhadap hasil pembangunan infrastruktur perdesaan adalah belum maksimalnya pemanfaatan dan atau tidak berkelanjutannya sarana dan prasarana yang telah dibangun. Untuk dapat menjadikan sarana dan prasarana yang dibangun berkelanjutan diperlukan dukungan dari beberapa aspek seperti teknis, kelembagaan, keuangan, peran serta masyarakat dan aspek lingkungan.

\subsection{Pembangunan Perdesaan}

Pembangunan menurut Todaro (2000) dalam Sigalingging (2014) diartikan sebagai suatu proses perubahan sosial dengan partisipatori yang luas dalam suatu masyarakat yang dimaksudkan untuk mencapai kemajuan sosial dan material (termasuk bertambah besarnya keadilan, kebebasan dan kualitas lainnya yang dihargai) untuk mayoritas rakyat melalui kontrol yang lebih besar terhadap lingkungan mereka. Pada hakekatnya pembangunan harus mencerminkan perubahan total suatu masyarakat atau penyesuaian sistem sosial secara keseluruhan, tanpa mengabaikan keragaman kebutuhan dasar dan keinginan individual maupun kelompok-kelompok sosial yang ada di dalamnya, untuk bergerak maju menuju suatu kondisi yang lebih baik, secara material maupun spiritual.

Menurut Anonim (2002) kawasan perdesaan adalah kawasan yang mempunyai kegiatan utama pertanian termasuk pengelolaan sumber daya alam dengan susunan fungsi kawasan sebagai tempat permukiman perdesaan, pelayanan jasa pemerintahan, pelayanan sosial dan kegiatan ekonomi.

Menurut Hardianti et al. (2017) keberhasilan pembangunan desa yang berlangsung di desa disamping di tentukan oleh partisipasi masyarakat juga nilai-nilai tradisional yang mendasari keterlibatan masyarakat sebagai potensi yang dapat digerakan dalam pembangunan melalui strategi manajemen yang sesuai. Untuk mewujudkan pembangunan berkelanjutan di suatu daerah, diperlukan komponen penduduk yang berkualitas. Karena dari penduduk yang berkualitas itulah memungkinkan untuk bisa mengolah dan mengelola potensi sumber daya alam 
dengan baik, tepat, efesien dan maksimal dengan tetap menjaga kelestarian lingkungan.

\section{METODE PENELITIAN}

Metode penelitian ini menggunakan metode penelitian kualitatif dengan pendekatan studi kasus. Digunakannya penelitian kualitatif dengan pendekatan studi kasus karena penelitian ini membutuhkan eksplorasi, observasi secara mendalam pada setiap tahapan perencanaan pembangunan di Desa Kerta. Sasaran dan target penelitian ini adalah Pemerintah Desa Kerta, masyarakat Desa Kerta dan kelembagaan, hal ini dikarenakan tiga komponen ini yang menjadi penggerak utama disetiap tahapan pembanguann Desa Kerta mulai dari perencanaan, pemanfaatan dan pengendalian.

Teknik penetuan informan dalam penelitian ini menggunakan teknik sampling purposive sampling dan snowball sampling. Informan yang terpilih nantinya adalah yang mengetahui tahapan dalam pembangunan desa mulai dari tahapan perencanaaan. Informan yang terpilih adalah Perbekel Desa Kerta, perangkat desa, masyarakat Desa Kerta dan kelompok sadar wisata (Pokdarwis) Desa Kerta. Teknik pengumpulan data pada penelitian ini dilakukan dengan wawancara dan observasi lapangan. Observasi yang gunakan adalah observasi non partisipan yang dimana peneliti tidak terlibat dan hanya sebagai pengamat independen. Sedangkan teknik wawancara yang dilakukan adalah dengan teknik wawancara tidak terstruktur, yang bertujuan agar wawancara bersifat terbuka. Dalam penelitian ini proses analisis data kualitatif menggunakan analisis data selama dilapangan model Miles dan Huberman. Menurut Miles \& Huberman (1984) dalam Sugiyono (2017) mengemukakan bahwa aktivitas dalam analisis data kualitatif dilakukan secara interaktif dan berlangsung secara terus menerus sampai tuntas, sehingga datanya sudah jenuh. Aktifitas dalam analisis data yaitu reduksi data (data reduction, penyajian data (data display), dan conclusion drawing/verification.

\section{HASIL DAN PEMBAHASAN}

Desa Kerta merupakan desa yang terletak di Kecamatan Payangan, kabupaten Gianyar. Desa Kerta ditetapkan menjadi desa definitif pada tahun 1958. Secara administratif Desa Kerta terdiri dari delapan dusun dan delapan desa adat. Desa Kerta merupakan kawasan perdesaan dan juga menjadi kawasan agropolitan 
Kabupaten Gianyar dan kawasan agrowisata. Secara keseluruhan luas wilayah Desa Kerta adalah 1442.3 Ha yang terbagi menjadi delapan dusun yaitu Dusun Mawang, Dusun Penyabangan, Dusun Kerta, Dusun Margatengah, Dusun Saren, Dusun Seming, Dusun Bunteh, Dusun Pilan.

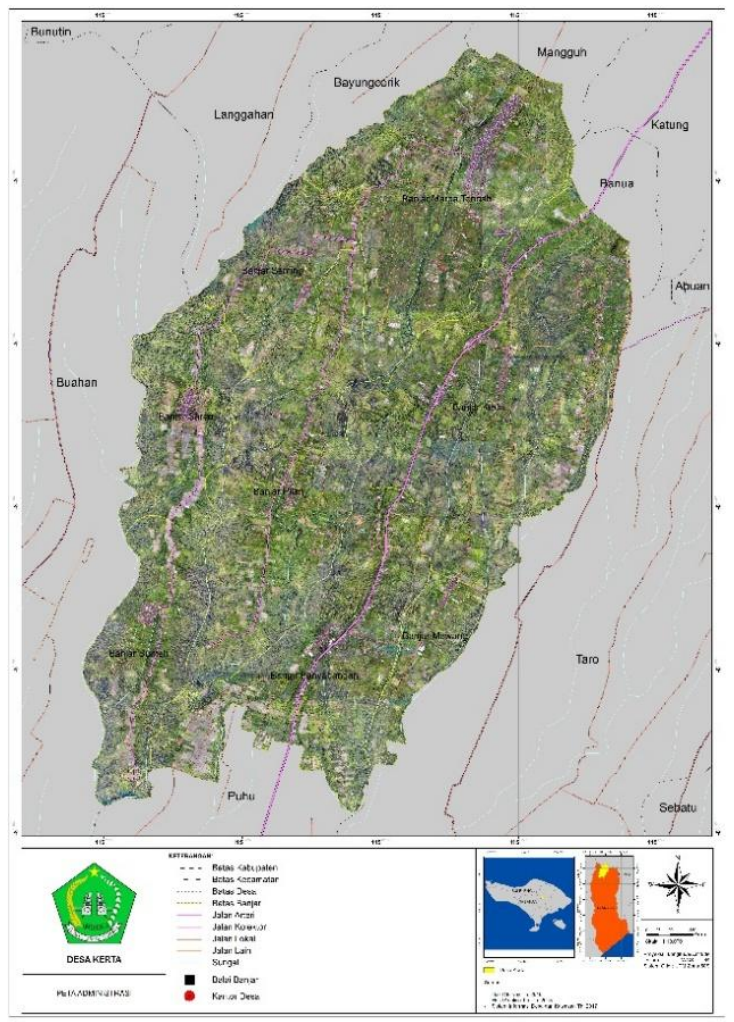

Gambar 1. Peta Administrasi Desa Kerta (Sumber: Profil Desa Kerta, 2018)

Identifikasi perkembangan ruang di Desa Kerta mengacu pada saat awal penyusunan Rencana Pembangunan Jangka Menengah Desa Kerta (RPJMDes) Kerta. Pada saat penyusunan RPJMDes ini identifikasi terhadap permasalahan yang dialami di Desa Kerta terutama pada permasalah infrastruktur. RPJMDes ini menjadi awal dari seluruh perencanaan yang akan dilakukan selama enam tahun kedepan sejak tahun 2014. Kondisi infrastruktur kawasan perdesaan di Desa Kerta sebelum tahun 2014 belum adanya perkerasan atau masih berupa tanah pada jalan desa dan jalan usaha tani yang ada di Desa Kerta. Hal ini menjadi penghambat utama dalam distribusi hasil pertanian, karena masyarakat kesulitan mengakses langsung tegalan dengan roda empat untuk dapat memindahkan hasil pertanian, hanya dengan roda dua tegalan dapat dijangkau, sehingga hal ini membutuhkan waktu yang lumayan lama untuk distribusi hasil pertanian.

Adapun permasalahan infrastruktur yang terjadi di Desa Kerta yang menyebabkan terhambatnya kegiatan masyarakat Desa Kerta dalam pendistribusian hasil pertanian adalah jalan usaha tani, jalan desa dan drainase. Permasalahan jalan usaha tani dan jalan lingkungan terlihat pada belum adanya perkerasan jalan, dan kondisi sudah terdapat perkerasan namun rusak. Permasalahan drainase terlihat pada kondisi drainase yang rusak dan belum adanya drainase. Kondisi permasalahan infrastruktur ini terjadi di seluruh dusun yang ada di Desa Kerta sebagai berikut pada Tabel 1. 
Tabel 1. Permasalah Infrastruktur Disetiap Dusun

\begin{tabular}{|c|c|c|c|c|c|c|c|}
\hline \multirow[b]{2}{*}{ No } & \multirow[b]{2}{*}{ Dusun } & \multicolumn{2}{|c|}{ Jalan usaha tani } & \multicolumn{2}{|c|}{ Jalan desa } & \multicolumn{2}{|c|}{ Drainase } \\
\hline & & $\begin{array}{c}\text { Tanpa } \\
\text { perkerasan }\end{array}$ & $\begin{array}{c}\text { Perkerasan } \\
\text { dan rusak }\end{array}$ & $\begin{array}{c}\text { Tanpa } \\
\text { Perkerasan }\end{array}$ & $\begin{array}{c}\text { Perkerasan } \\
\text { dan rusak }\end{array}$ & $\begin{array}{c}\text { Ada, Tidak } \\
\text { berfungsi }\end{array}$ & Ada, rusak \\
\hline 1 & Penyabangan & & $\bullet$ & & $\bullet$ & & $\bullet$ \\
\hline 2 & Kerta & & - & & - & & - \\
\hline 3 & Mawang & & - & & - & & - \\
\hline 4 & Margatengah & & - & & - & - & \\
\hline 5 & Pilan & - & & - & & - & \\
\hline 6 & Saren & - & & - & & - & \\
\hline 7 & Bunteh & - & & - & & - & \\
\hline 8 & Seming & - & & - & & - & \\
\hline
\end{tabular}

Identifikasi permasalahan Dokumen RPJMDes ini nantinya akan infrastruktur seperti Tabel 1 menjadi awal menjadi acuan program kegiatan setiap dalam penyusunan RPJMDes Kerta Tahun tahunnya yang dapat dilaksanakan sesuai 2014-2020. Pemerintah Desa Kerta dapat dengan kebutuhan infrastruktur. Sehingga menyusun skala prioritas dalam pada Tahun 2015 awal pembangunan penanganan permasalahan, dan melakukan perencanaan terhadap kebutuhan infrastruktur pun dilaksanakan hingga masyarakat di bidang infrastruktur. tahun 2019 (Tabel 2).

Tabel 2. Pembangunan Infrastruktur di Desa Kerta Tahun 2015-2019

\begin{tabular}{|c|c|c|c|c|}
\hline No & $\begin{array}{c}\text { Jenis } \\
\text { Infrastruktur }\end{array}$ & Kegiatan & $\begin{array}{l}\text { Lokasi } \\
\text { (Dusun) }\end{array}$ & Tahun \\
\hline 1 & $\begin{array}{l}\text { Jalan usaha } \\
\text { tani }\end{array}$ & Rabat beton jalan akses lahan Tempekan Sengkiding & Kerta & 2017 \\
\hline 2 & $\begin{array}{l}\text { Jalan usaha } \\
\text { tani }\end{array}$ & Rabat beton jalan akses lahan Padang Puuk & Mawang & 2017 \\
\hline 3 & $\begin{array}{l}\text { Jalan usaha } \\
\text { tani }\end{array}$ & Rabat beton jalan usaha tani & Saren & 2017 \\
\hline 4 & $\begin{array}{l}\text { Jalan usaha } \\
\text { tani }\end{array}$ & Pemeliharaan jalan usaha tani & Bunteh & 2019 \\
\hline 5 & Jalan desa & Rabat beton balan di Br. Bunteh & Bunteh & 2015 \\
\hline 6 & Jalan desa & Pembukaan jalan di Br. Penyabangan & Penyabangan & 2015 \\
\hline 7 & Jalan desa & Rabat beton dan penahan tanah di Br. Saren & Saren & 2015 \\
\hline 8 & Jalan desa & Peningkatan jalan jurusan Penyabangan-Mawang & $\begin{array}{l}\text { Penyabangan- } \\
\text { Mawang }\end{array}$ & 2016 \\
\hline 9 & Jalan desa & Perbaikan jalan jurusan Penyabangan-Pilan & $\begin{array}{l}\text { Penyabangan- } \\
\text { Pilan }\end{array}$ & 2016 \\
\hline 10 & Jalan desa & $\begin{array}{l}\text { Peningkatan jalan dengan rabat beton di Banjar Dinas } \\
\text { Saren }\end{array}$ & Saren & 2016 \\
\hline 11 & Jalan desa & Rabat beton jalan lingkungan Br. Saren & Saren & 2017 \\
\hline 12 & Jalan desa & Rabat beton jalan lingkungan Sema Bangsel-Kancasidem & Kerta & 2017 \\
\hline 13 & Jalan desa & Rabat beton jalan Petiratan Bhujangga & Margatengah & 2019 \\
\hline 14 & Drainase & Drainase senderan jalan di Br. Margatengah Timur & Margatengah & 2015 \\
\hline 15 & Drainase & Pembuatan drainase di Banjar Dinas Kerta & Kerta & 2016 \\
\hline 16 & Drainase & Drainase Br. Bunteh & Bunteh & 2017 \\
\hline
\end{tabular}


Kegiatan pembangunan infrastruktur berupa jalan usaha tani, jalan lingkungan, drainase menjadi prioritas kegiatan yang dilakukan sejak tahun 2015 hingga 2019, baik pembangunan maupun pemeliharaan. Masyarakat dan Pemerintah Desa Kerta fokus pada tahun tersebut untuk dapat merampungkan kegiatan pembangunan infrastruktur agar masyarakat tidak lagi menemukan permasalahan pada akses transportasi dan distribusi kegiatan pertanian. Upaya yang dilakukan oleh Pemerintah Desa Kerta dan kelembagaan masyarakat yang ada di Desa Kerta selain mempermudah akses distribusi hasil pertanian juga agar mewadahi potensi yang ada yaitu salah satunya dengan pemenuhan infrastruktur, dikarenakan saat ini potensi yang ada tidak dapat diperkenalkan secara maksimal terkendala dari akses untuk dapat menikmati potensi yang ada.

Setelah pembangunan infrastruktur dilakukan di Desa Kerta selama kurun waktu lima tahun sejak tahun 2015 hingga tahun 2019, yang menjadi prioritas pembangunan adalah jalan usaha tani, jalan desa dan drainase. Terbangunnya infrastruktur yang sesuai dengan kebutuhan masyarakat, maka masyarakat dapat melakukan kegiatan pendistribusian hasil pertanian dengan baik. Permbangunan infrastruktur menjadi awal dari perkembangan ruang baru yang ada di Desa Kerta. Setelah infrastrukur terbangun, masyarakat memulai untuk memanfaatkan infrastruktur yang telah terbangun, masyarakat Desa Kerta memulai untuk memanfaatkan infrastruktur yang ada dengan kegiatankegiatan yang rutin dilakukan oleh masyarakat Desa Kerta. Jalan usaha tani dimanfaatkan untuk pendistribuasi kegiatan pertanian. Jalan desa dimanfaatkan untuk akses menghubungkan antara dusun. Drainase dimanfaatka untuk dapat mengaliri air agar sesuai dengan alirannya. Masyarakat Desa Kerta sangat memanfaatkan dengan baik infrastruktur yang telah dibangun.

Selanjutnya upaya yang dilakukan Pemerintah Desa Kerta, masyarakat dan kelembagaan berupa kelompok sadar wisata Desa Kerta (Pokdarwis) adalah menggali potensi yang ulai terlihat pasca pembangunan infrastruktur. Hal yang terkait dengan potensi yang dimiliki oleh Desa Kerta dimanfaatkan menjadi daya tarik wisata. Pemerintah Desa Kerta dan Pokdarwis mengidentifikasi potensi masing-masing dusun yang ada, dan dikelompokkan berupa:

1. Dusun dengan potensi perkebunan jeruk dan pertanian holtikultura yang terdiri dari 
Dusun Margatengah, Dusun Pilan, Dusun Kerta dan Dusun Saren.

2. Dusun dengan potensi perkebunan campuran terdiri dari Dusun Mawang, Dusun Penyabangan, Dusun Bunteh dan Dusun Saren.

Setelah dilakukan identifikasi kelompok dusun selanjutnya dipetakan potensi-potensi yang ada di masing-masing dusun. Pemetaan potensi ini menjadi tahapan setelah dilakukan pembangunan infrastruktur. Selain bertujuan untuk identifikasi potensi juga bertujuan untuk pemanfaatan ruang menjadi wisata desa. Pada Gambar 2 pemetaan potensi Desa Kerta yang merupakan hasil kajian dari pemerintah desa dan kelembagaan masyarakat.

Dari identifikasi potensi yang dilakukan oleh Pemerintah Desa Kerta dan kelembagaan masyarakat, dan pembangunan infrastruktur yang telah dimanfaatkan oleh masyarakat Desa Kerta. Pemanfaatan ruang dan pemanfaatan infrastruktur dimasing-masing dusun yang ada di Desa Kerta disesuaikan dengan potensi dan kondisi dari infrastruktur yang telah terbangun. Adapun uraian dari pemanfaatan ruang dan pemanfaatan infrastruktur yang telah berkembang sampai saat ini adalah sebagai berikut:

\section{Dusun Margatengah}

Infrastruktur berupa jalan usaha tani yang telah terbangun di Dusun Margatengah dimanfaatkan menjadi jalur trekking mengelilingi perkebunan jeruk yang ada. Sedangkan pemanfaatan ruang yang ada disekitar infrastruktur yang telah terbangun masih belum terlihat dalam upaya pemanfaatan ruangnya.

\section{Dusun Seming}

Infrastruktur yang terbangun berupa jalan desa dengan rabat beton. Pemanfaatan infrastruktur jalan desa menjadi jalur cycling. Sedangkan pemanfaatan ruang yang ada disekitar infrastruktur yang telah terbangun masih belum terlihat dan dimanfaatkan.

\section{Dusun Saren}

Infrastruktur yang terbangun di Dusun Saren berupa jalan desa dan jalan usaha tani dengan perkerasan beton. Pemanfaatan infrastruktur jalan usaha tani dan jalan desa di Desa Kerta ini menjadi jalur cycling. Pemanfaatan ruang yang ada disekitar jalan usaha tani dan jalan desa masih belum dimanfaatkan. 


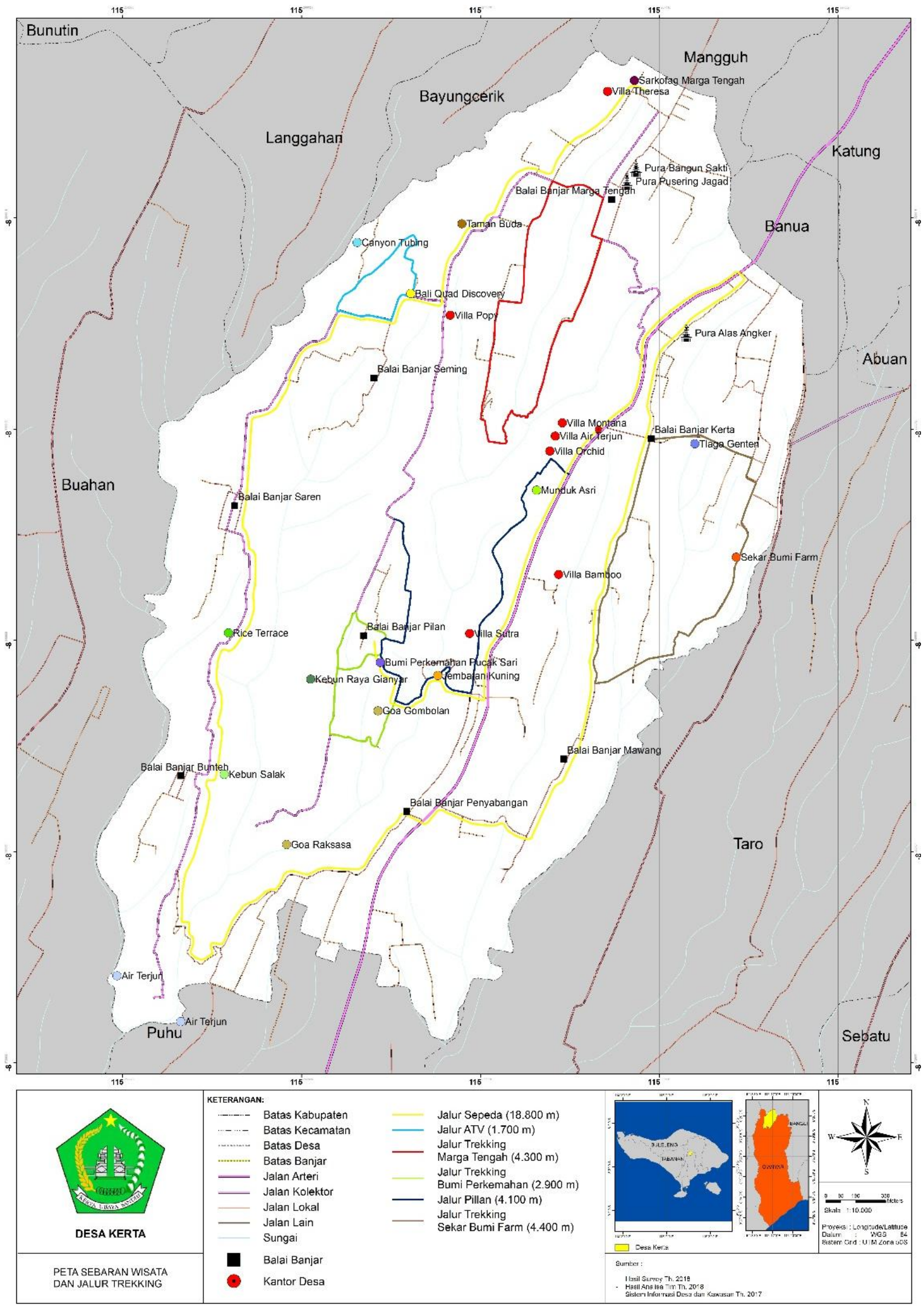

Gambar 2. Pemetaan Potensi Desa Kerta Kajian Pemerintah Desa Kerta dan Kelembagaan Masyarakat

(Sumber: Dokumen Desa Kerta, 2019) 
4. Dusun Pilan.

Infrastruktur yang terbangun di

Dusun Pilan berupa jalan usaha tani. Pembangunan jalan usaha tani di Dusun Pilan ini dimanfaatkan menjadi trekking. Selain itu pembukaan jalan yang menghubungkan Dusun Penyabangan dan Dusun Pilan menjadi salah satu pembangunan infastruktur yang ada di Dusun Pilan. Pemanfaatan ruang di setelah pembangunan infrastruktur di Dusun Pilan terlihat dengan berkembangnya ruang yang semula merupakan lahan kosong milik desa adat dikembangkan menjadi bumi perkemahan Puncak Sari, dikarenakan akses menuju tempat ini telah dipermudah karena sudah terdapat perkerasan menuju bumi perkemahan dan pembukaan jalan terlah dilaksanakan.

\section{Dusun Bunteh}

Infrastruktur yang terbangun di Dusun Bunteh berupa jalan desa. Pemanfaatan infrastruktur jalan desa ini dijadikan jalur cycling. Sedangkan pemanfaatan ruang yang ada disekeliling pembangunan infrastruktur belum dimanfaatkan.

6. Dusun Penyabangan
Infrastruktur yang terbangun di Dusun Penyabangan berupa jalan desa dan jalan usaha tani. Pemanfaatan infrastruktur jalan desa dan jalan usaha tani dijadikan jalur cycling. Sedangkan untuk pemanfaatan ruang masih belum dimanfaatkan ruang sekitar pembangunan infrastruktur.

7. Dusun Mawang

Infrastruktur yang terbangun di Dusun Mawang berupa jalan desa. Pemanfaatan infrastruktur jalan desa ini dimanfaatkan menjadi jalur cycling. Sedangkan untuk pemanfaatan ruang disekitar pembangunan infrastruktur yang telah terbangun masih belum dimanfaatkan.

\section{Dusun Kerta}

Infrastruktur yang terbangun di Dusun Kerta berupa pembangunan drainase dan senderan jalan. Sedangkan untuk jalan desa di Dusun Kerta sudah dalam kondisi baik. Pemanfaatan infrastruktur di Dusun Kerta berupa pembangunan senderan jalan dan drainase dilanjutkan dengan pemanfaatan ruang disekitar drainase untuk ditanami bunga potong. Sehingga pemanfaatan ruang sekitar drainase 
menjadi perkebunan bunga potong dan pembibitan bunga potong. Hal ini tentunya menciptakan ruang baru untuk wisata desa berupa agrowisata bunga potong.

Pada uraian perkembangan ruang dan infrastruktur dari masing-masing dusun diatas memperlihatkan bahwa setiap dusun yang ada di Desa Kerta sejak tahun 2014 hingga tahun 2019 seluruh dusun melakukan perencanaan dengan pengajuan usulan yang berasal dari masyarakat masing-masing dusun pada saat penyusunan RPJMDes Tahun 2014 dan pembangunan di realisasikan mulai tahun 2015 hingga 2019. Terlihat dari delapan dusun yang ada di Desa Kerta perkembangan infrastrukturnya mengarah pada pembangunan jalan desa dan jalan usaha tani, dan pembangunan drainase. Setelah adanya pembangunan infrastruktur pada delapan dusun, terlihat perkembangan yang terjadi pada dua tahun terakhir yaitu tahun 2018 dan 2019, bahwa dusun-dusun yang mulai berkembang dan memanfaatkan infrastruktur yang ada ditandai dengan memanfaatkan potensi yang ada dan menjadikan wisata desa. Dua dusun yaitu Dusun Pilan dan Dusun Kerta yang dapat melakukan pemanfaatan infrastruktur dan pemanfaatan ruang dengan beriringan.
Berdasarkan teori pembangunan desa yang dikemukakan oleh Rondinelli (1982) dalam bahwa pemanfaatan hasil pembangunan fisik desa yaitu dengan membangun atau memperbaiki prasarana jalan desa akan menciptakan atau memperbaiki kehidupan masyarakat desa. Dengan adanya pembangunan prasarana jalan, masyarakat dapat menggunakan jalan tersebut dengan berbagai kebutuhan yang mereka perlukan, seperti melakukan mobilitas, pemasaran hasil pertaniannya, mangangkut hasil pertanian agar lebih mudah dan lain-lain. Jika dikaitkan dengan yang ada di Desa Kerta pembangunan Desa Kerta memang berawal dari pembangunan fisik infrastruktur desa, yaitu dengan memperbaiki dan membangun infrastruktur yang mendukung seluruh aktivitas utama bagi masyarakat Desa Kerta yang didominasi bergerak dibidang pertanian yaitu berupa membangun atau memperbaiki jalan usaha tani, jalan desa dan drainase yang ada. Sampai saat ini tahun 2019 infrastruktur yang ada di Desa Kerta sangat mengalami perubahan dan membantu masyarakat Desa Kerta dalam melakukan mobilisasi mengangkut hasil pertanian.

Teori pengembangan wilayah, yang salah satunya adalah konsep agropolitan dikembangkan oleh Friedman dan Douglas 
(1975) menekankan pentingnya pendekatan agropolitan dalam pengembangan perdesaan di kawasan Asia dan Afrika. Pembangunan infrastruktur yang intensif untuk mendukung pemanfaatan potensi sumber daya alam akan mampu mempercepat pengembangan wilayah tersebut. Dalam konteks ini Pemerintah Desa Kerta belum menggunakan konsep Agropolitan menjadi salah satu pendekatan dalam pengembangan wilayah di Desa Kerta. Masyarakat dan Pemerintah Desa Kerta hanya beranggapan pembangunan infrastruktur akan menjadi awal dari sebuah wilayah akan berkembang. Dengan adanya infrastruktur akan membuat ruangruang yang ada di Desa Kerta lebih bermanfaat secara maksimal.

\section{SIMPULAN DAN SARAN}

Pemanfaatan infrastruktur dan ruang yang ada di Desa Kerta secara beriringan dalam kurun waktu lima tahun yaitu tahun 2015 hingga tahun 2019 terlihat di Dusun Pilan dan Dusun Kerta. Pemanfaatan infrastruktur di Dusun Pilan dimaksimalkan untuk membuka akses menuju lahan kosong miliki desa adat dan dijadikan bumi perkemahan. Sedangkan di Dusun Kerta pasca pembangunan drainase dan senderan jalan, area dipinggir jalan dimanfaatkan untuk ditanami bunga potong dan menjadi wisata desa dengan pertanian bunga potong. Pemanfaatan infrastruktur dan ruang pasca pembangunan infrastruktur ini terlihat dengan maksimal dikarenakan potensi secara maksimal telah tergali di dua dusun tersebut. Sedangkan enam dusun lainnya pemanfaatan infrastruktur saja yang sudah optimal namun pemanfaatan ruang sekitar infrastruktur yang terbangun masih belum terlihat berkembang dan dimanfaatkan menjadi wisata desa. Pembangunan infrastruktur menjadi awal dari sebuah wilayah akan dapat berkembang dengan menggali potensi yang dimiliki. Hal ini jika dilakukan sesuai dengan perencanaan maka enam dusun lainnya di Desa Kerta akan dapat secara maksimal memanfaatkan ruang yang ada disekeliling infrastruktur yang telah terbangun dengan baik menjadi wisata desa.

Penelitian ini dapat menjadi acuan bagi desa yang melakukan perencanaan dan pembangunan infrastruktur di kawasan perdesaan, yang memiliki potensi alam maupun potensi buatan yang dapat dikembangkan menjadi wisata desa. Dengan mengacu pada kebutuhan infrastruktur oleh masyarakat kawasan perdesaan, yang selanjutnya dilakukan perencanaan infrastruktur, pembangunan 
infrastruktur, pemanfaatan infrastruktur dan pemanfaatan ruang yang ada disekitar infrastruktur yang telah terbangun.

\section{DAFTAR PUSTAKA}

Aldillah, D. (2020). Fungsi Infrastruktur Jembatan Bagi Perubahan Masyarakat Kelurahan Lempake Kecamatan Samarinda Utara. Journal Sosiatri-Sosiologi, 8 (1), 7286.

Anonim. (2002). Glosasary perKim. Jakarta: Direktorat Jenderal Perumahan dan Permukiman Departemen Permukiman dan Prasarana Wilayah.

Asnudin, A. (2009). Pembangunan Infrastruktur Perdesaan Dengan Pelibatan Masyarakat Setempat. Jurnal SMARTek, 7 (4), 292-300.

Gai, A. M., Witjaksono, A., \& Maulida, R. R. (2020). Perencanaan dan Pengembangan Desa. Malang: CV. Dream Litera Buana.

Hardianti, S., Muhammad, H., \& Lutfi, M. (2017). Partisipasi Masyarakat Dalam Pembangunan Infrastruktur Desa (Program Alokasi Dana Desa Di Desa Buntongi Kecamatan Ampana Kota). Jurnal Katalogis, 5 (1), 120-126.

Holis, Y. M. (2017). Local Economic Linkages Pada Kota Kecil/Menengah Sebagai Instrumen Konsep Keterkaitan Desa-Kota (Rural-Urban Linkage). Institut Teknologi Bandung: http://pasca.unand.ac.id/id/prosidingseminar-nasional-perencanaanpembangunan-inklusif-desa-kota.

Kasikoen, K. M. (2011). Keterkaitan Antar Wilayah Studi Kasus Kabupaten Cilacap. Jurnal Teknik Planologi, 2 (2).
Mustar, S. (2019). Panduan Sederhana Pembangunan Infrastruktur Untuk Perdesaan Perencanaan Infrastruktur Perdesaan. Jakarta: PT. Mediatama Saptakarya.

Pranoto, S. M., Syamsul, M., Surjonoo, H. S., \& Hermanto, S. (2006). Pembangunan Perdesaan Berkelanjutan Melalui Model Pengembangan Agropolitan. Jurnal Manajemen Agribisnis, 3 (1).

Prastyanti, S. (2015). Pendekatan Pembangunan dan Pengentasan Kemiskinan di Pedesaan. Jurnal Acta diurnal, 11 (1).

Rudita, I K. P. (2012). Potensi Obyek Wisaya dan Keterpaduannya dalam Pengembangan Kawasan Agropolitan Payangan, Kabupaten Gianyar Provinsi Bali. Jurnal Lanskap Indonesia, 4 (1).

Saraswaty, A. (2013). Strategi Pengembangan Infrastruktur Berbasis Komoditi Unggulan di Kawasan Agropolitan Kabupaten Soppeng. Jurnal Perencanaan dan Pengembangan Wilayah.

Sigalingging, A. H. (2014). Partisipasi Masyarakat Dalam Partisipasi Pembangunan (Studi Kasus Pada Kecamatan Sidikalang Kabupaten Dairi). Jurnal Administrasi Publik, 2 (2).

Solekhan, M. (2014). Penyelenggaraan Pemerintahan Desa Berbasis Partisipasi Masyarakat. Malang: Setara Press.

Suroyo, B. T. (2014). Pengembangan Kawasan Agropolitan di Kabupaten Kulonprogo, Daerah Istimewa Yogyakarta. Jurnal Perencanaan Wilayah dan Kota, 25 (3).

Wahid, Y. (2014). Pengantar Hukum Tata Ruang. Jakarta: Prenadamedia Group. 